DOI: https://doi.org/10.31933/jimt.v2i6 Received: 21 Mei 2021, Revised: 25 Juni 2021, Publish: 15 Agustus 2021

JIMT
JUINASTI
JERALILMU MANAJEMEN
TERAPAN

\title{
ANALISIS BID ASK SPREAD PADA MASA SESUDAH RIGHT ISSUE DITINJAU DARI HARGA SAHAM, VOLUME PERDAGANGAN DAN RETURN SAHAM
}

\author{
Fitri Yeni ${ }^{1}$, Risa Melani Putri ${ }^{2}$, Elfiswandi Elfiswandi ${ }^{3}$, Lusiana Lusiana ${ }^{4}$, Mondra \\ Neldi $^{5}$ \\ ${ }^{1)}$ Mahasiswa Program Doktor Manajemen, Universitas Putra Indonesia YPTK, Padang, Indonesia, \\ fitri_yeni@upiyptk.ac.id \\ 2) Universitas Putra Indonesia YPTK, Padang, Indonesia, risamelaniputri3@gmail.com \\ ${ }^{3)}$ Universitas Putra Indonesia YPTK, Padang, Indonesia, elfiswandi@ upiyptk.ac.id \\ 4) Universitas Putra Indonesia YPTK, Padang, Indonesia, lusiana@upiyptk.ac.id \\ ${ }^{5)}$ Universitas Putra Indonesia YPTK, Padang, Indonesia, mondraneldi@upiyptk.ac.id
}

\section{Corresponding Author: Fitri Yeni ${ }^{1}$}

Abstrak: Salah satu hal yang perlu diperhatikan investor dalam perdagangan saham adalah bid ask spread terutama bagi investor yang berharap menerima capital gain atas investasinya, hal ini dikarenakan dianggap merupakan biaya dalam perdagangan saham. Tujuan penelitian ini adalah untuk melihat sejauh mana harga saham, volume perdagangan dan return saham mempengaruhi bid ask spread. Populasi dari penelitian yaitu seluruh perusahaan yang terdaftar di Bursa Efek Indonesia tahun 2015-2019 yaitu 714 perusahaan dengan jumlah sampel 41 perusahaan. Penarikan sampel menggunakan metode purposive sampling dengan kriteria yang telah ditetapkan. Analisis data menggunakan regresi linier berganda dengan aplikasi program eviews 9. Temuan dari penelitian ini bahwa harga saham berpengaruh negatif dan signifikan terhadap bid ask spread sedangkan volume perdagangan berpengaruh positif dan signifikan terhadap bid ask spread dan return saham tidak berpengaruh signifikan terhadap bid ask spread.

Kata Kunci: Harga Saham, Volume Perdagangan, Return Saham, Bid Ask Spread.

\section{PENDAHULUAN}

Perusahaan memerlukan dana untuk membiayai aktivitas operasional dari perusahaannya. Dana tersebut biasanya diperoleh dari beberapa sumber, seperti dana yang dari dalam dan dari luar perusahaan. Modal dari pemilik dan juga laba ditahan merupakan bentuk pendanaan dari dalam perusahaan sedangkan pinjaman atau utang dari pihak lainnya merupakan bentuk pandanaa dari luar perusahaan. Sebagian perusahaan go public melakukan penerbitan sekuritas dapat dijadikan sumber dana tambahan untuk aktivitas operasionalnya melalui pasar modal selain dari melakukan pinjaman. Pada saat akan berinvestasi di bursa efek kecenderungan investor memperhatikan besarnya keuntungan yang didapatkan dan 
seberapa besar resiko yang akan dihadapi. Mengatasi hal tersebut perusahaan harus mampu memperlihatkan kepada publik bahwa kinerja dari keuangan perusahaan baik.

Perusahaan memiliki dua cara untuk menawarkan saham kepada para investor yaitu dengan secara umum dan terbatas. Penawaran saham kepada investor secara keseluruhan merupakan penawaran saham secara umum sebaliknya penawaran secara terbatas yaitu penawaran saham dengan harga saham yang biasanya lebih rendah dari pada harga di pasaran kepada investor lama yang mengakibatkan investor akan menjadi tertarik untuk memutuskan membeli saham tersebut, penawaran terbatas inilah yang disebut dengan right issue. Alfred Nainggolan sebagai kepala riset koneksi kapital, mengatakan bahwa "Pada tahun 2019 peluang aktivitas rights issue lebih banyak dibanding dengan tahun sebelumnya. Dapat dibuktikan dari aspek perekonomian yang sebagian besar lembaga serta regulator keuangan memprediksikan keadaan perekonomi akan menjadi lebih baik. Jumlah dari rights issue sepanjang tahun 2018 turun menjadi 28 aksi dengan nilai Rp 35,45 triliun. Sedangkan di tahun 2017 jumlah aksi right issue tercatat sebanyak 35 aksi adapun nilainya sebesar Rp 88,2 triliun. Ini berarti rights issue di 2018 mengalami penurunan jumlah dan nilai sebanyak $20 \%$ dan 59\% (www.kontan.co.id, 2019).

Proses menjual dan membeli saham di pasar uang akan menghasilkan bid price dan ask price. Bid price adalah harga beli tertinggi, dan ask price merupakan harga jual terendah. Oleh sebab itu, bid ask spread menggambarkan rentang jarak dari harga beli tertinggi dengan harga jual saham terendah (Yulia and Ikramaturrabiah, 2018). Jika bid ask spread tinggi maka potensi untung akan menjadi lebih besar, tetapi bila terlalu tinggi akan menjadikan saham tersebut diperdagangan kurang aktif. Sebaliknya, jika bid ask spread rendah maka akan menjadikan saham tersebut lebih aktif diperdagangkan. Tetapi, bila terlalu rendah maka keuntungan yang di hasilkan pun berpotensi rendah juga. Hal tersebut membuat para pelaku pasar berupaya untuk memastikan tingkatan bid ask spread maksimal yakni mendapatkan keuntungan yang diharapkan, namun saham tersebut tetap aktif diperdagangkan.

Harga saham merupakan harga pasar dari saham saat perdagangan berlangsung dengan mempertimbangkan permintaan serta penawaran atas saham tersebut (Hamidah, Maryadi and Ahmad, 2018). Rengifuryaan, Diana and Junaidi (2019) mengemukakan harga saham merupakan surat sebagai bukti tanda pemilikan perusahaan perseroan terbatas atas investasi modal sehingga diberikan hak atas dividen perusahaan tersebut. Tingginya harga saham menunjukkan semakin kuatnya persaingan diantara para pelaku pasar. Ketatnya persaingan berpengaruh terhadap harga beli (bid) yang relatif naik dan harga jual (ask) yang relatif turun sehingga menyebabkan spread akan menyempit

Volume perdagangan merupakan rasio dari keseluruhan lembar saham yang diperjual belikan pada suatu waktu dibandingkan dengan keseluruhan saham yang beredar waktu tersebut (Rio, Husnatarina and Oktavia, 2020). Investor lebih tertarik dengan saham yang memiliki return yang cukup tinggi meski mempunyai resiko. Pertumbuhan harga saham serta volume perdagangan merupakan indikator yang perlu diperhatikan dalam melihat tingkah laku investor di pasar modal. Meningkatnya volume perdagangan bisa menambahkan informasi bermanfaat bagi investor untuk berkelanjutan selama periode perdagangan dimana rendahnya volume perdagangan akan mengakibatkan jatuhnya harga saham. Besarnya minat atas saham maka semakin mendorong harga saham lebih tinggi. 
Return saham merupakan hal yang berguna untuk mempertimbangkan suatu investasi terhadap suatu saham. Return merupakan tingkatan keuntungan yang didapat seorang pemodal dari investasinya. Yusra (2019) mengemukakan return ialah hasil yang didapatkan dari aktivitas investasi yang dilakukan. Return juga dapat berarti laba yang bisa dinyatakan dengan tarif presentase tahunan dari suatu investasi. Tujuan setiap investor berinvestasi yaitu untuk mendapatkan 'return' Willen dan Abubakar (2016). Terdapat 2 sumber return yaitu capital gain dan dividen. Keuntungan yang didapatkan pada saat harga jual lebih besar dari pada harga beli saham disebut sebagai capital gain. Sebaliknya dividen ialah bagian dari keuntungan perusahaan yang menjadi hak milik investor ataupun pemegang saham sesuai dengan porsi kepemilikannya. Besarnya return yang diperoleh disebabkan oleh harga penjualan saham yang semakin tinggi dibandingkan dengan harga belinya. Jika investor berkeinginan memperoleh nilai return yang tinggi maka resiko yang diterima akan tinggi juga. Bila investor ingin menanggung resiko yang rendah maka return yang diterima akan rendah juga (Ramadhan dan Aulia, 2019)

Penelitian yang dilakukan oleh Khoirayanti dan Sulistiyo (2020); Hamidah, Maryadi dan Ahmad (2018) menemukan terdapatnya pengaruh harga saham serta volume perdagangan saham terhadap bid ask spread. Utami et al., (2020) menemukan adanya pengaruh return saham dan volume perdagangan terhadap bid ask spread. Temuan penelitian Kurniawan dan Afriyenti (2019) yaitu volume perdagangan, harga saham, serta return saham berpengaruh terhadap bid ask spread. Berdasarkan uraian diatas dan temuan dari beberapa hasil penelitian yang telah dilakukan oleh beberapa peneliti terdahulu maka tujuan dari penelitian ini adalah untuk mengetahui bagaimana pengaruh harga saham, volume perdagangan serta return saham terhadap bid ask spread pada masa sesudah right issue.

\section{KAJIAN PUSTAKA}

\section{Teori Sinyal (Signalling Theory)}

Teori sinyal mengungkapkan tentang bagaimana sinyal yang seharusnya diberikan oleh perusahaan kepada para pengguna dari laporan keuangan perusahaan. Publikasi dari laporan keuangan yang dilakukan perusahaan diharapkan mampu memperkecil asimetris informasi. Dengan demikian investor secara keseluruhan akan mendapatkan informasi yang sama mengenai kinerja keuangan dari perusahaan sehingga perbedaan antara harga permintaan dan penawaran akan lebih rendah (Wahyuliantini dan Suarjaya, 2015).

\section{Right Issue}

Right ialah surat berharga yang memberikan hak untuk menukarkan (exercise) menjadi saham biasa kepada pemegang saham (Rengifuryaan, Diana and Junaidi, 2019). Pemegang saham lama yang mempertahankan proporsional saham yang dimilikinya pada perusahaan emiten akan mendapat keuntungan dengan adanya penerbitan right issue. Pada saat penerbitan right issue harga pasar biasanya lebih tinggi dari pada harga pelaksanaan. Right diprioritaskan untuk pemegang saham biasa agar memesan saham baru dan diberikan begitu saja. Apabila saham barunya tidak dibeli maka kepemilikan saham akan menurun. Right issue yaitu hak yang diberikan oleh emiten untuk memesan saham perusahaan yang akan dijual terlebih dahulu kepada pemegang saham lama dengan harga tertentu agar 
keterbatasan modal perusahaan bisa diatasi dengan berbagai kepentingan perusahaan diantaranya ekspansi, restrukturisasi dan lainnya.

\section{Bid Ask Spread}

Bid price disebut juga sebagai harga tertinggi yang diberikan dealer atau harga yang ditawarkan untuk membeli saham oleh dealer. Harga terendah yang ditawarkan dealer disebut juga dengan ask price, sehingga pada saat kondisi ini dealer bersedia untuk menjual sahamnya (Dewi dan Kartika, 2015). Dalam biaya transaksi salah satu hal penting ialah spread harga antara bid dan ask. Biaya ini berkaitan dengan keinginan dealer dalam memperdagangkan saham yang milikinya. Perbedaan harga bid dan ask disebut sebagai Spread. Jadi, bid ask spread yaitu selisih dari harga jual dan beli. Menurut Widhyawati dan Damayanthi (2015) dealer dalam menentukan kewajaran dari spread ialah dengan mempertimbangkan informasi juga kejadian tertentu yang berkaitan dengan sekuritas yang mereka miliki. Besarnya asimetri informasi disebabkan spread yang ditentukan oleh dealer karena informasi yang didapat oleh dealer memerlukan biaya informasi. Dealer akan mengajukan harga yang mereka inginkan disaat investor ingin membeli saham. Apabila seorang investor ingin menjual saham maka dealer pun memberikan harga penawaran. Dengan demikian dealer saham menentukan bid ask spread dari saham suatu perusahaan. Dealer siap untuk melakukan pembelian maupun penjualan pada kisaran harga yang sudah ditetapkan ini. Investor bisa bertransaksi sesuai permintaan dengan dibukakannya jalan oleh dealer dan dealer bertindak sebagai perantara antara penjual dan pembeli.

\section{Harga Saham}

Harga saham ditentukan oleh hukum permintaan dan penawaran. Meningkatnya permintaan suatu saham akan mengakibatkan meningkatnya harga saham tersebut. Banyaknya saham yang dijual oleh pemiliknya mengakibatkan harga dari saham tersebut akan mengalami penurunan. Harga saham yaitu harga dari saham yang ada di pasar modal pada suatu waktu dimana pelaku pasar merupakan pihak penentu harga yang dipengaruhi oleh permintaan dan penawaran dari saham tersebut (Yusra, 2019). Besarnya harga saham ditentukan oleh jumlah akan permintaan terhadap saham tersebut. Ini berarti harga penutupan merupakan harga saham pada pasar rill. Naiknya harga saham mendorong terciptanya capital gain, sedangkan menurunnya harga saham akan menimbulkan capital loss. Pada penelitian ini harga saham yaitu harga saham setelah penutupan (closing price) yang tercatat pada setiap akhir periode dengan skala pengukuran dengan menggunakan skala rasio dalam satuan rupiah (Rp).

\section{Volume Perdagangan Saham}

Volume perdagangan $(\mathrm{Vt})$ didefinisikan sebagai keseluruhan dari lembar saham yang diperjual belikan pada hari ke-t. Volume perdagangan ialah keseluruhan dari lembar saham yang di perdagangkan dihari tertentu (Dewi dan Kartika, 2015). Keseluruhan saham yang ditransaksikan di pasar modal oleh para investor disebut juga dengan volume perdagangan. Meningkatnya tingkat penjualan dan pembelian saham oleh para investor adalah bukti selisih lebih dari volume perdagangan. Besarnya volume perdagangan pada saat penawaran dan 
permintaan saham mengakibatkan pengaruh yang tinggi pula terhadap kecenderungan naik dan turunnya harga dari saham di bursa. Ini berarti bahwa banyaknya masyarakat yang berminat terhadap suatu saham ditandai dengan meningkatnya volume perdagangan saham tersebut sehingga akan mempengaruhi naiknya harga saham (Rosdiana, 2019). Perdagangan dalam volume besar pada suatu pasar modal akan diprediksi sebagai tanda kondisi suatu pasar mulai membaik. Meningkatnya volume perdagangan diiringi pula dengan kanaikan harga merupakan gejala yang makin kuat akan keadaan pasar yang membaik. Aktifnya suatu saham diperdagangan dapat dilihat dari tingginya volume perdagangan. Hal ini menunjukkan besarnya minat para investor terhadap suatu saham sehingga dapat dengan mudah diperdagangkan.

\section{Return Saham}

Pengembalian yang diperoleh investor atas investasi yang dilakukannya disebut sebagai return. Sederhananya return disebut sebagai keuntungan atau hasil dari penanaman modal. Return merupakan keuntungan yang diperoleh seorang investor saat menanamkan modalnya pada suatu investasi salah satunya seperti surat berharga. Motivasi investor dalam berinvestasi diantaranya adalah return yang juga merupakan imbalan bagi investor dalam menanggung resiko dari investasinya. Ada dua macam return pada dasarnya yaitu dividen dan capital gain/loss. Return saham juga ada dua jenis yaitu return realisasi dan ekspektasi (expected return). Keuntungan yang diperoleh salah satunya dari hasil investasi yang dilakukan baik oleh individu maupun instansi adalah dalam bentuk laba yang disebut juga dengan return saham, laba tersebut bisa dalam bentuk bunga atau dividen pada periode tertentu tergantung kepada jenis investasi yang dipilih.

Berdasarkan uraian dan kajian Pustaka diatas, berikut dirumuskan hipotesis dari penelitian ini:

$\mathrm{H}_{1}$ : Harga saham berpengaruh terhadap bid ask spread.

$\mathrm{H}_{2}$ : Volume perdagangan berpengaruh terhadap bid ask spread.

$\mathrm{H}_{3}$ : Retun saham berpengaruh terhadap bid ask spread.

$\mathrm{H}_{4}$ : Harga saham, volume perdagangan dan return saham berpengaruh terhadap bid ask spread.

\section{METODE PENELITIAN}

Penelitian ini dilakukan pada perusahaan yang terdaftar di Bursa Efek Indonesia (BEI) dengan rentang periode 2015-2019. Data yang digunakan adalah data sekunder yang bersifat historis selama periode penelitian. Jenis penelitian ini yaitu deskriptif dengan pendekatan yang digunakan adalah kuantitatif. Analisis data menggunakan metode analisis regresi linier berganda dengan menggunakan aplikasi program eviews 9.

Populasi dari penelitian yaitu perusahaan yang terdaftar di Bursa Efek Indonesia (BEI) pada rentang waktu 2015 - 2019 berjumlah 714 perusahaan. Sampel yang diambil sebanyak 41 perusahaan dengan teknik yang digunakan ialah purposive sampling, yaitu pengambilan sampel dengan tujuan, pertimbangan, atau kriteria tertentu. Adapun kriterianya adalah; saham yang secara aktif diperdagangkan di Bursa Efek Indonesia selama periode penelitian yaitu Januari 2015 - Desember 2019, perusahaan yang mengumumkan right issue 
selama periode penelitian dan data emiten yang lengkap yang tidak berkaitan dengan pengumuman right issue.

\section{Variabel Penelitian}

Harga saham yaitu harga penutupan (closing price) perdagangan tahunan saham selama periode penelitian (Rengifuryaan, Diana dan Junaidi, 2019). Harga saham yang digunakan pada penelitian ini adalah harga penutupan (closing price).

Volume perdagangan ialah jumlah keseluruhan lembar saham yang diperdagangkan diwaktu tertentu, baik harian, mingguan, bulanan maupun tahunan (Yulia dan Ikramaturrabiah, 2018). Volume perdagangan dapat di ukur dengan Jumlah keseluruhan lembar saham yang diperjual belikan pada waktu tertentu.

Return saham merupakan perolehan pengembalian yang diterima investor atas investasi yang dilakukannya. Return saham bisa berupa yang sudah terjadi yang disebut juga dengan return realisasi atau yang belum terjadi akan tetapi dimasa datang diharapkan akan terjadi yang disebut juga dengan return ekspektasi (Yusra, 2019). Return saham pada penelitian ini dihitung menggunakan sebagai berikut:

$$
\mathrm{Rt}=\frac{\mathrm{Pt}-\mathrm{Pt}-1}{\mathrm{Pt}-1}
$$

Bid-ask spread adalah selisih dari harga tertinggi dan terendah dari suatu saham pada periode tertentu (Yulia dan Ikramaturrabiah, 2018). Formula yang digunakan dalam menghitung Bid Ask Spead sebagai berikut:

$$
\text { Bid ask spread }=\frac{(\text { Ask spread }- \text { Bid price })}{(\text { Ask price }+ \text { Bid price }) 1 / 2}
$$

\section{Teknik Analisis Data}

Pada penelitian ini analisis data dengan menggunakan analisis regresi linier berganda, dengan menggunakan aplikasi program eviews 9 .

Berikut persamaan analisis regresi linier berganda;

$\mathrm{Y}=\mathrm{a}+\mathrm{b}_{1} \mathrm{X}_{1}+\mathrm{b}_{2} \mathrm{X}_{2}+\mathrm{b}_{3} \mathrm{X}_{3}+\mathrm{e}$

dengan ketentuan:

Y : Bid Ask Spread

$\mathrm{X}_{1}$ : Harga Saham

$\mathrm{X}_{2}$ : Volume Perdagangan

$\mathrm{X}_{3}$ : Return Saham

a : Konstanta

$\mathrm{b}_{1}$ : Koefisien Regresi Harga Saham

$\mathrm{b}_{2}$ : Koefisien Regresi Volume Perdagangan

$\mathrm{b}_{3}$ : Koefisien Regresi Return Saham

e : Standar error 


\section{HASIL DAN PEMBAHASAN}

Setelah semua informasi dan data terkumpul langkah selanjutnya adalah melakukan pengolahan data menggunakan aplikasi program eviews 9. Hasil pengolahan data tersebut dapat diperoleh hasil statistik deskriptif dari variabel-variabel penelitian yang terlihat pada tabel berikut:

Tabel 1. Hasil Statistik Deskriptif

\begin{tabular}{lcccc}
\hline \hline & & & \\
& Harga Saham & Volume & & \\
& Perdagangan & Return Saham & Bid Ask Spread \\
\hline \hline Mean & 12.651 & 14.273 & 0.123 & 10.947 \\
Median & 11.662 & 14.314 & 0.000 & 10.700 \\
Maximum & 30.000 & 22.117 & 1.000 & 24.218 \\
Minimum & 1.005 & 4.605 & -0.999 & 1.000 \\
Std. Dev. & 7.461 & 3.313 & 0.352 & 4.934 \\
Observations & 205 & 205 & 205 & 205 \\
\hline \hline
\end{tabular}

Berdasarkan hasil pada tabel 1 menunjukkan dari 205 observasi, data bid ask spread berkisar antara 1,000 sampai 24,218 dimana nilai tengah (median) berjumlah 10,700 sedangkan rata-rata (mean) berjumlah 10,947 dengan standar deviasi 4,934. Harga saham berkisar antara 1,005 sampai 30,000 dimana nilai tengah (median) berjumlah 11,662 sedangkan rata-rata (mean) berjumlah 12,651 dengan standar deviasi 7,461. Volume perdagangan berkisar antara 4,605 sampai 22,117 dimana nilai tengah (median) berjumlah 14,314 sedangkan rata-rata (mean) berjumlah 14,273 dengan standar deviasi 3,313. Return saham berkisar antara -0,999 sampai 1,000 dimana nilai tengah (median) berjumlah 0,000 sedangkan rata-rata (mean) berjumlah 0,123 dengan standar deviasi 0,352.

\section{Uji Asumsi klasik}

Dari uji normalitas diperoleh hasil menggunakan nilai Jarque-Bera berjumlah 0,92 dengan probability 0,63 dapat simpulkan bahwa dalam model penelitian ini residualnya telah berdistribusi dengan normal. Sedangkan pengujian multikolinearitas dilakukan dengan menggunakan VIF (Variance Inflatin Factor) dan masing-masing variabel independen yang digunakan koefisien korelasinya telah dibawah 10 yang artinya data terbebas dari gejala multikolinearitas. Uji heteroskedastisitas nilai probability observasi $\mathrm{R}$-squared yang diperoleh berjumlah 0,091. Dari hasil yang didapatkan tersebut menunjukkan bahwa nilai probability 0,091 > 0,05 ini berarti bahwa seluruh variabel pada penelitian telah terhindar dari gejala heteroskedastisitas.

\section{Analisis Regresi Linier Berganda}

Tabel 2. Hasil Estimasi Regresi Linier Berganda

\begin{tabular}{crrrr}
\hline \hline Variable & Coefficient & Std. Error & t-Statistic & Prob. \\
\hline \hline C & 6.995 & 1.509 & 4.636 & 0.000 \\
HS & -0.247 & 0.040 & -6.238 & 0.000 \\
VP & 0.504 & 0.089 & 5.643 & 0.000 \\
RS & -1.007 & 0.823 & -1.224 & 0.222 \\
\hline \hline R-squared & 0.316 & Mean dependent var & 10.947 \\
Adjusted R-squared & 0.306 & S.D. dependent var & 4.934
\end{tabular}




\begin{tabular}{lrll} 
S.E. of regression & 4.111 & Akaike info criterion & 5.684 \\
Sum squared resid & 3396.496 & Schwarz criterion & 5.749 \\
Log likelihood & -578.650 & Hannan-Quinn criter. & 5.711 \\
F-statistic & 30.951 & Durbin-Watson stat & 0.860 \\
Prob(F-statistic) & 0.000 & & \\
\hline
\end{tabular}

Tabel diatas menunjukkan persamaan regresi linier berganda pada sebagai berikut:

$$
\mathrm{BAS}=6,995-0,247 \mathrm{HS}+0,504 \mathrm{VP}-1,007 \mathrm{RS}+\mathrm{e}
$$

Hasil persamaan regresi menunjukkan bahwa varibel koefisien dari variable harga saham memiliki nilai negatif yaitu $-0,247$ hal ini berarti korelasi harga saham dengan bid ask spread bernilai negatif dimana kenaikan 1 satuan harga saham akan diikuti dengan turunnya bid ask spread sebesar -0,247. Variabel volume perdagangan memiliki koefisien bernilai positif yaitu 0,504 artinya korelasi volume perdagangan dengan bid ask spread bernilai positif dimana kenaikan 1 satuan volume perdagangan akan diikuti dengan naiknya bid ask spread sebesar 0,504. Variabel return saham memiliki koefisien negatif yaitu $-1,007$ hal ini berarti bahwa korelasi return saham dengan bid ask spread bernilai negatif yang artinya jika return saham meningkat 1 satuan maka akan diikuti dengan turunnya bid ask spread sebesar -1,007. Nilai R-squared sebesar 31,6\% ini menunjukkan kemampuan variabel harga saham, volume perdagangan dan return saham mempengaruhi bid ask spread sedangkan sisanya 68,4\% lagi merupakan pengaruh dari variabel lainnya.

\section{Uji t}

Pada tabel 2 menunjukkan hasil dari uji t kolom prob. Data pada tabel terlihat bahwa probability harga saham 0,000 lebih kecil dari 0,05 atau $(0,000<0,05)$ artinya variabel harga saham secara parsial berpengaruh negatif dan signifikan terhadap bid ask spread dengan demikian hipotesis satu diterima. Utami et al., (2020); Hamidah, Maryadi dan Ahmad (2018); Surya (2016) melakukan penelitian dan menemukan hasil yang sama yaitu harga saham berpengaruh negatif dan signifikan terhadap bid ask spread. Hal ini menandakan bahwa bid ask spread akan menurun jika harga saham semakin naik. Aktifnya suatu saham diperdagangkan akan mengakibatkan harga saham tersebut semakin naik. Investor tidak akan menahan saham yang dimilikinya lebih lama jika saham tersebut aktif diperdagangkan. Akibatnya biaya kepemilikan semakin menurun dan spread akan menyempit.

Variabel volume perdagangan pada tabel diatas memiliki nilai probability 0,000 lebih kecil dari alpha 0,05 atau $(0,000<0,05)$ dapat diartikan bahwa adanya pengaruf positif dan signifikan variabel volume perdagangan terhadap bid ask spread, dengan demikian hipotesis dua diterima. Penelitian Khoirayanti dan Sulistiyo (2020); Rengifuryaan, Diana dan Junaidi (2019); Kurniawan dan Afriyenti (2019) menemukan hasil yang sama yaitu terdapatnya pengaruh yang positif dan signifikan volume perdagangan terhadap bid ask spread. Tidak sejalan dengan temuan penelitian Rosdiana (2019) bahwa tidak adanya pengaruh volume perdagangan terhadap bid ask spread.

Besarnya volume perdagangan akan memperkecil nilai dari bid ask spread dan jika volume perdagangan kecil maka nilai bid ask spread akan memperbesar. Likuiditas suatu saham sangat ditentukan oleh volume perdagangan dari saham tersebut dengan demikian 
saham tidak perlu disimpan oleh dealer terlalu lama. Saham yang disimpan tidak terlalu lama akan menyebabkan biaya kepemilikan dari saham tersebut menurun sehingga nilai dari bid ask spread saham tersebutpun ikut menurun. Sesuai dengan sinyal teori, perusahaan yang melakukan pengumuman right issue merupakan pemberian sinyal oleh perusahaan kepada publik. Berhasil atau tidaknya sinyal yang diberikan oleh perusahaan kepada investor dapat diukur dari volume perdagangan saham. Right issue dinyatakan memberikan sinyal baik kepada investor apabila volume perdagangan meningkat. Informasi pasar modal juga penilaian yang dilakukan terhadap saham bisa mengacu kepada volume perdagangan. Kecilnya volume perdagangan mengindikasikan investor kurang tertarik melakukan investasi, sedangkan investor dikatakan berminat berinvestasi pada suatu saham bila volume perdagangan besar yang menunjukkan banyaknya transaksi jual dan beli saham.

Return saham memiliki probability sebesar 0,222 lebih besar dari alpha 0,05 atau $(0,222>0,05)$ dapat diartikan bahwa tidak adanya pengaruh yang signifikan return saham terhadap bid ask spread. Dengan demikian hipotesis tiga penelitian ini ditolak. Penelitian yang dilakukan oleh Alkusani, Handayani dan Rahmadani (2020) menemukan hasil yang sama yaitu tidak adanya berpengaruh yang signifikan return saham terhadap bid ask spread.

\section{Uji F}

Pada tabel 2 diatas terlihat nilai dari hasil pengujian F pada Prob ( $F$-statistik) sebesar 0,000 lebih kecil dari alpha 0,05 atau $(0,000<0,05)$ artinya bahwa variabel harga saham, volume perdagangan dan return saham berpengaruh signifikan terhadap bid ask spread, sehingga hipotesis empat penelitian ini diterima.

\section{KESIMPULAN DAN SARAN}

Berdasarkan pembahasan dan analisis data diatas maka disimpulkan bahwa terdapat pengaruh yang negatif dan signifikan harga saham terhadap bid ask spread sedangkan volume perdagangan memiliki pengaruh positif dan signifikan terhadap bid ask spread dan return saham tidak memiliki pengaruh yang signifikan terhadap bid ask spread. Variabel Harga saham, volume perdagangan dan return saham berpengaruh signifikan terhadap bid ask spread. Investor diharapkan lebih memperhatikan hal-hal yang mempengaruhi harga saham dikarenakan mempengaruhi bid ask spread secara negatif dan investor juga perlu memperhatikan prediksi arah dan hubungannya dengan volume perdagangan dikarenakan mempengaruhi bid ask spread secara positif.

\section{DAFTAR RUJUKAN}

Alkusani, Handayani, A., \& Rahmadani, Y. F. (2020). Linkage Stock Price, Trading Volume Activity, Stock Returns and Trading Frequency on Bid Ask Spread Alkusani. IRJ: Innovation Research Journal Linkage, 1(1), 28-33.

Dewi, A. N. A., \& Kartika, I. (2015). Faktor-Faktor Yang Mempengaruhi Bid-Ask Spread Pada Perusahaan Manufaktur. Jurnal Akuntansi Indonesia, 4(2), 83-96.

Hamidah, Maryadi, S., \& Ahmad, G. N. (2018). Pengaruh Harga Saham, Volatilitas Harga Saham, Dan Volume Perdagangan Saham Terhadap Bid-Ask Spread Saham Pada Perusahaan Sektor Pertambangan Yang Terdaftar Di Issi Periode Juni 2016-Juni 2017. Jurnal Riset Manajemen Sains Indonesia (JRMSI), 9(1), 147-169. 
Khoirayanti, R. N., \& Sulistiyo, H. (2020). Pengaruh Harga Saham, Volume Perdagangan, Dan Frekuensi Perdagangan Terhadap Bid-Ask Spread. JIAFE (Jurnal Ilmiah Akuntansi Fakultas Ekonomi), 6(2), 231-240.

Kurniawan, D., \& Afriyenti, M. (2019). Pengaruh Harga Saham, Volume Perdagangan, dan Varian Return Terhadap Bid-Ask Spread (Studi Empiris pada Perusahaan yang Melakukan Stock Split yang Terdaftar di Bursa Efek di Asia Tenggara Tahun 2018). Wahana Riset Akuntansi, 7(1), 1397-1414.

Ramadhan, Z., \& Aulia, D. (2019). Faktor-Faktor Yang Mempengaruhi Return Saham Pada Perusahaan Sub Sektor Kosmetik Dan Keperluan Rumah Tangga Yang Terdaftar Di Bursa Efek Indonesia. Journal of Applied Business and Economics (JABE) Vol., 6(1), 54-69.

Rengifuryaan, F., Diana, N., \& Junaidi. (2019). Pengaruh Harga Saham, Varian Return, Volume Perdagangan Dan Abnormal Return Terhadap Bid - Ask Spread Pada Masa Sebelum Dan Sesudah Right Issue ( Studi Empiris Pada Perusahaan yang Listing di Bursa Efek Indonesia Periode 2015-2018 ). E-JRA Fakultas Ekonomi Dan Bisnis Universitas Islam Malang, 08(04), 65-79.

Rio, P. P., Husnatarina, F., \& Oktavia, R. (2020). Pengaruh Ukuran Perusahaan, Volume Perdagangan Saham, Volatilitas Return Saham, Dan Dividend Yield Terhadap Bid-Ask Spread (Studi Empiris Pada Perusahaan Manufaktur yang terdaftar di Bursa Efek Indonesia Periode 2014-2018). Jurnal Pasar Modal Dan Bisnis, 2(1), 29-44.

Rosdiana, D. (2019). Pengaruh Harga Saham Dan Volume Perdagangan Saham Terhadap Bid Ask Spread Dina. Jurnal Manajemen Dan Bisnis Vol., 3(3).

Surya, K. (2016). Pengaruh Harga Saham, Volume Perdagangan, Market Value Dan Varian Return Terhadap Bid Ask Spread ( Studi Empiris pada Perusahaan yang Terdaftar di Daftar Efek Syariah) The Effect Of Stock Price, Trading Volume, Market Value, And Variance Return To T. 2013.

Utami, F. A., Sadalia, I., \& Muda, I. (2020). Determinant of Bid - Ask Spread Share on LQ45 Index Emitents in Indonesia. International Journal of Research and Review, 7(June), 143-151.

Wahyuliantini, N. M., \& Suarjaya, A. A. G. (2015). Pengaruh Harga Saham , Volume Perdagangan Saham, Dan Volatilitas Return Saham Pada Bid-Ask Spread. Jurnal Manajemen, Strategi Bisnis Dan Kewirausahaan, 9(2), 146-155.

Widhyawati, I. G. A. M., \& Damayanthi, I. G. A. E. (2015). Pengaruh Trading Volume, Market Value, Dan Return Variance Pada Bid-Ask Spread. E-Jurnal Akuntansi Universitas Udayana, 10(3), 763-777.

Willen, N., \& Abubakar, H. (2016). Analisis Pengaruh Stock Split Terhadap Return Saham , Volume Perdagangan Saham , Price Earning Ratio, Price To Book Value, Dan Earning Per Share Pada Perusahaan Yang Terdaftar Di Bursa Efek Indonesia Periode 2013-2016 Nicholas Willen Haitami Abubakar *. Program Studi Akuntansi Kwik Kian Gie School of Bussiness, $v(021)$.

Yulia, A., \& Ikramaturrabiah. (2018). Pengaruh Internal Control, Volatilitas Saham, dan Volume Perdagangan Terhadap Bid-Ask Spread Pada Perusahaan Yang Terdaftar Dalam Indeks LQ45 Tahun 2011-2015. Jurnal Pendidikan Akuntansi Dan Keuangan, $6(1), 1-10$.

Yusra, M. (2019). Pengaruh Frekuensi Perdagangan, Trading Volume, Nilai Kapitalisasi Pasar, Harga Saham, Dan Trading Day Terhadap Return Saham Pada Perusahaan Kosmetik Dan Keperluan Rumah Tangga Di Bursa Efek Indonesia. Jurnal akuntansi dan keuangan, 7(1), 65-74. 